\title{
Building a Replacement Sour Orange Rootstock: Somatic Hybridization of Selected Mandarin + Pummelo Combinations
}

\author{
Jude W. Grosser1, Victor Medina-Urrutia², Govindarajulu Ananthakrishnan, and \\ Patricia Serrano \\ Department of Horticulture, University of Florida, IFAS, Citrus Research and Education Center, 700 \\ Experiment Station Road, Lake Alfred, FL 33850
}

\begin{abstract}
AdDitional INDEX wORDs. citrus tissue culture, citrus tristeza virus (CTV), disease resistance, protoplast fusion, somatic embryogenesis

AвSTRACT. Sour orange has been a premier citrus rootstock worldwide due to its ability to perform on challenging soils and to produce and hold high-quality fruit. However, increasingly widespread quick-decline isolates of citrus tristeza virus (CTV) have destroyed entire industries on sour orange in some countries, and are in the process of destroying millions of trees on sour orange in Florida. CTV also threatens other citrus locations planted heavy to sour orange, including Texas and Mexico. An acceptable alternative rootstock to replace sour orange is in high demand but has yet to be developed. Molecular analyses have recently determined that sour orange is probably a hybrid of pummelo and mandarin. We report the production of 12 new mandarin + pummelo somatic hybrids produced by protoplast fusion from selected superior mandarin and pummelo parents, in efforts to develop a suitable replacement sour-orange-like rootstock that is resistant to CTV-induced quick decline. Somatic hybrids from all 12 parental combinations were confirmed by a combination of leaf morphology, flow cytometry, and RAPD analyses (for nuclear hybridity). These new mandarin + pummelo somatic hybrids are being propagated by rooted cuttings as necessary to conduct quick-decline resistance assays and to assess horticultural performance in replicated field trials.
\end{abstract}

Sour orange (Citrus aurantium L.) has historically been a widely planted and high-performance rootstock of international stature. Trees on this rootstock produce good yields of high-quality fruit that store on the tree longer than most other common citrus rootstocks. They are also resistant to gummosis and foot rot caused by Phytophthora spp., cold-hardy, tolerant of salt and exocortis and xyloporosis viroids, field-tolerant of citrus blight, and grow well in a range of soils (Castle et al., 1993; Hodgson, 1967; Saunt, 1990). Unfortunately, trees of most commercial scions on sour orange rootstock are also highly susceptible to quick-decline disease caused by citrus tristeza virus (CTV) (Bar Joseph et al., 1989), especially sweet orange (Citrus sinensis L. Osbeck) and grapefruit (C. paradisi Macf.). CTV is vectored by aphids that feed on citrus, especially the brown citrus aphid Toxoptera citricida Kirk. This insect/virus combination has virtually destroyed entire citrus industries, e.g., Venezuela and Brazil, and eliminated any further use of sour orange rootstock (Yokomi et al., 1994). The brown citrus aphid arrived in Florida several years ago and has accelerated the demise of sour orange rootstock in Florida (Brown and Spreen, 2000). Most of the remaining $\approx 15$ million sour orange-rooted trees in Florida are expected to die within the next decade. Citrus industries in Texas and Mexico are in jeopardy because $>90 \%$ of their trees are on sour orange

Received for publication 25 July 2003. Accepted for publication 17 Dec. 2003. This research was supported by the Florida Agricultural Experiment Station, and approved for publication as journal series R-09581. The authors thank the Fundacion Produce Colima, Fundacion Produce Michoacan, and CONACYTSimorelos No. 980301008 (Mexico), and the Florida Citrus Production Research Advisory Council, the USDA/IFAS Cooperative Agreement on Exotic Diseases of Citrus, and the USDA/CSREES (USA) for grants that supported this research. The authors also thank Jim Graham for assistance with prescreening the pummelo seedlings.

${ }^{1}$ Corresponding author; e-mail jwg@lal.ufl.edu.

${ }^{2}$ Current address: INIFAP-Campo Experimental Tecoman, KM 35 Carretera Colima-Manzanillo Tecoman, Colima CP28100, Mexico. (the brown citrus aphid is now moving through Mexico). To date, tested alternative rootstocks, especially for sweet orange and grapefruit, have proven to be inadequate in many cases as replacements for sour orange for several reasons, including lack of adaptation, lower fruit quality, horticultural problems (including delayed bearing, small fruit size, or undesirable tree size, etc.), or susceptibility to other diseases. Clearly, development of an alternative rootstock that performs similarly to sour orange but that is resistant to CTV-induced quick decline when budded with sweet orange or grapefruit is a high priority.

Recent molecular marker analyses have shown that sour orange is probably a hybrid of pummelo $(C$. grandis $\mathrm{L}$. Osb.) with mandarin (C. reticulata Blanco) (Nicolosi et al., 2000). Both of these ancestral species are considered to be two of the four progenitor species in Citrus, from which all other citrus cultivars have been derived (the other two being citron $(C$. medica) and C. micrantha (Barrett and Rhodes, 1976; Nicolosi et al., 2000). Considering rootstock genetics, it is unlikely that the original sour orange was synthesized from the best pummelo or mandarin. The hypothesis for the present research is that superior sour-orange-like rootstock hybrids can be produced by combining mandarin and pummelo parents selected for good rootstock attributes. Hybrids are being produced at the tetraploid level via somatic hybridization to preserve the dominant traits of the parents, and to increase potential for tree size control (Grosser et al., 1995, 1998, 2000; Grosser and Chandler, 2002). Somatic hybridization also provides an opportunity for immediate use of selected pummelo seedlings as parents, since flowering is not a requirement as in conventional breeding. Other diploid hybrids containing mandarin and pummelo are known to be tolerant of CTV when used as rootstocks, including sweet orange (Citrus sinensis), C. obovoideae (Kinkoji), and Smooth Flat Seville (SFS) (considered to be a complex hybrid possibly involving pummelo, sour orange, and/or sweet orange) (Castle et al., 1992, 1993). 
Each of these alternative rootstocks have limited use for various reasons, i.e., sweet orange is susceptible to Phytophthora, Kinkoji doesn't produce adequate seed for nursery propagation, and SFS produces a high percentage of zygotic seedlings, many of which are CTV susceptible and/or produce trees of variable size (J.W. Grosser and W.S. Castle, unpublished data). Lower juice quality may also be a limiting factor for Kinkoji and SFS (Castle, 2003). Along with sour orange, these rootstocks also show good field-tolerance to citrus blight. Blight is not generally observed on these rootstocks until the trees are $>20$ years old, and then it occurs at a low frequency. Rootstock hybrids containing mandarin and pummelo also generally produce fruit with medium-good quality. In contrast, popular rootstocks that have citron in their ancestry (Nicolosi et al., 2000) are generally highly susceptible to blight, cold-sensitive, and produce high yields of poor-quality fruit; these include rough lemon ( $C$. jambhiri Lush), Volkamer lemon (C. volkameriana Pasq.), rangpur ( $C$. limonia Osbeck), and Palestine sweet lime (C. limettioides Tan.) (Castle, 1987). These facts suggest that pummelo may be a better parent than citron for maximizing heterosis in hybrid rootstock production. Pummelo has largely been ignored by rootstock breeders because it is monoembryonic and produces all hybrid seed, and citrus rootstocks are traditionally propagated by polyembryonic seed that produce nucellar seedlings. However, we do not view this as a major problem since it is known that a high percentage of $\mathrm{F}_{1}$ hybrids between pummelo and sweet orange produce nucellar seed (Jose Chaparro, personal communication). Moreover, alternative methods of propagation such as micropropagation or rooted cuttings could be used for a superior rootstock.

Three highly nucellar and seedy mandarin types were selected for this research based primarily on soil adaptation. Amblycarpa mandarin (Citrus amblycarpa Ochse) is highly polyembryonic and was suggested as a possible rootstock for use in California (Hodgson, 1967). Mexican lime on Amblycarpa mandarin performed very well on several different soil types in Mexico, including a high $\mathrm{pH}$ soil with a high clay content (Medina-Urrutia, 1996). Persian lime (C. latifolia Tan.) trees on Amblycarpa mandarin planted in a site with high $\mathrm{pH}$ Rockdale soil were performing better than on several other rootstocks, including Cleopatra and Sun Chu Sha mandarins ( $C$. reticulata Blanco) in a 3-year-old trial that was subsequently destroyed because of canker (W.S. Castle, unpublished data). Shekwasha mandarin (C.depressa Hay.) was reported to grow vigorously in sandy-loam and porous-limestone soils of southeastern Florida and was suggested for testing as a rootstock (Campbell, 1991; Swingle and Reece, 1967). Its performance in Florida rootstock trials has been variable. 'Murcott' (a presumed tangor of unknown origin) has only recently been included in Florida rootstock trials, and limited performance information is available. Seedling populations are uniform, and trees grown on this rootstock are vigorous and seem to produce acceptable crops of good quality fruit (W.S. Castle, personal communication). In a 'Bearss' lemon trial, trees on 'Murcott' cropped relatively well and showed good cold tolerance (Castle, 1983).

Pummelo types used in this research were cultivars chosen for various traits, or selected zygotic seedlings previously screened for adaptation to high $\mathrm{pH}$, calcareous soil and Phytophthora resistance. 'Chandler' pummelo [C. maxima (Burm.) Merrill or C.-grandis (L.) Osbeck] was selected due to its known resistance to several CTV isolates (Fang and Roose, 1999). 'Hirado Buntan Pink' (HBP) pummelo is thought to be a chance seedling of the original 'Hirado Buntan' pummelo, which has yellow-fleshed fruit (M. Kesinger, personal communication) and was reported to be more cold hardy than other pummelos (Swingle and Reece, 1967). A somatic hybrid of 'Nova' mandarin hybrid + a seedling of 'Hirado Buntan Pink' is performing well as a rootstock in several locations, including one with high $\mathrm{pH}$, calcareous soil (Grosser and Chandler, 2002). The zygotic pummelo seedlings used as leaf parents were from a collection of $\approx 250$ healthy vigorous seedlings selected from a soil-Phytophthora screen conducted previously in collaboration with J.H. Graham (CREC) as follows. In total, 200 seed each of 11 standard pummelos were planted directly into flats of a high pH (8 to 8.5) calcareous Winder depressional soil collected directly from the Indian River citrus production area in Fort Pierce, Fla. (with higher clay content and pH than typical Winder soil because it was from a double-bedded area), that was inoculated with both Phytophthora nicotianae and P. palmivora. After 3 months, superior seedlings were selected and propagated for further study (including an assay for CTV resistance) and use in fusion experiments. New combinations of these superior mandarins and pummelos at the tetraploid level may provide new rootstocks with the adaptation and horticultural performance of sour orange, but with improved disease resistance and ability to control tree size. The objective of the present work was to apply highly successful citrus protoplast fusion techniques to develop several somatic hybrids that combine superior mandarin + pummelo types in efforts to develop an adequate replacement for sour orange rootstock.

\section{Materials and Methods}

Protoplast isolation, fusion, and culture. Embryogenic suspension cultures of Amblycarpa, Shekwasha, and 'Murcott' were initiated from friable embryogenic callus cultures maintained in the citrus embryogenic callus collection of the Univ. of Florida's Citrus Research and Education Center. Suspensionderived protoplasts were obtained from $\approx 1$-year-old suspension cultures that were continuously maintained in $\mathrm{H}+\mathrm{H}$ medium on a 2-week subculture cycle, with protoplasts isolated during days 4 to 12 (Grosser and Gmitter, 1990).

Recently grafted plants of 'Hirado Buntan Pink' and 'Chandler' pummelos and previously selected zygotic pummelo seedlings 'Chandler' \#80, 'Chandler' \#69, 'Hirado Buntan Pink' HBJL-1, 'Hirado Buntan Pink' HBJL-2B, Hirado Buntan Pink' 5-1-99-1B, and 'Ling Ping Yau zyg.' 8-1-99-4A were maintained in 1-gal pots in a low-light (via double shadecloth) greenhouse. Tender, fully expanded leaves from these plants were used to obtain leaf-derived protoplasts.

Protoplast isolation And Fusion. Protoplasts were isolated from the Amblycarpa, Shekwasha, and 'Murcott' suspension cultures in a 2.5:1.5 (v:v) mixture of $0.7 \mathrm{M} \mathrm{BH3}$ protoplast culture medium and enzyme solution according to Grosser and Gmitter (1990). Before protoplast isolation, selected leaves from greenhouse parental plants were decontaminated by immersion in $1 \mathrm{~N} \mathrm{HCl}$ for $5 \mathrm{~s}$, followed by immersion in $20 \%$ commercial bleach for $15 \mathrm{~min}$, and rinsed with sterile distilled water for 10 min. Sterile leaves were feather-cut with a sharp scalpel and incubated overnight (including a 25-min vacuum infiltration) in a $8: 3(\mathrm{v}: \mathrm{v})$ mixture of $0.6 \mathrm{M} \mathrm{BH} 3$ protoplast culture medium and enzyme solution (Grosser and Gmitter, 1990). Protoplasts from both sources were purified by passage through a $45-\mu \mathrm{m}$ stainless steel mesh screen and then centrifugation on a $25 \%$ sucrose/13\% mannitol gradient (Grosser and Gmitter, 1990).

The standard method of fusing embryogenic culture-derived protoplasts of one parent with leaf-derived protoplasts of the second 
Table 1. New allotetraploid mandarin + pummelo somatic hybrid plants produced by protoplast fusion.

\begin{tabular}{|c|c|c|c|}
\hline $\begin{array}{l}\text { Embryogenic } \\
\text { parent }\end{array}$ & Leaf parent & $\begin{array}{l}\text { No. of plants } \\
\text { regenerated from } \\
\text { fusion experiments }\end{array}$ & $\begin{array}{c}\text { Nursery } \\
\text { plant } \\
\text { vigorz }^{2}\end{array}$ \\
\hline 'Murcott' tangor & + C. grandis 'Hirado Buntan Pink' (HBP) & 3 & $\mathrm{H}$ \\
\hline 'Murcott' & + HBP sdl-JL-1 & 1 & $\mathrm{H}$ \\
\hline 'Murcott' & + 'Chandler' sdl. \#80 & $>50$ & $\mathrm{H}$ \\
\hline Amblycarpa mandarin (C. amblycarpa) & $+\mathrm{HBP}$ & $>50$ & $\mathrm{H}$ \\
\hline Amblycarpa & $+C$. grandis 'Chandler' & 24 & $\mathrm{H}$ \\
\hline Amblycarpa & + 'Chandler' sdl \#69 & $>50$ & M \\
\hline Amblycarpa & + HBP sdl-5-1-99-1B & $>50$ & $\mathrm{H}$ \\
\hline Amblycarpa & + HBP sdl-JL2B & $>50$ & $\mathrm{H}$ \\
\hline Amblycarpa & + 'LingPingYau'-sdl-8-1-99-4A & $>50$ & $\mathrm{H}$ \\
\hline Shekwasha mandarin $(C$. depressa) & $+\mathrm{HBP}$ & 11 & $\mathrm{~L}$ \\
\hline Shekwasha & + HBP sdl-JL2B & 2 & $\mathrm{~L}$ \\
\hline Shekwasha & + 'Chandler' & 2 & $\mathrm{~L}$ \\
\hline
\end{tabular}

zVigor rating: $\mathrm{H}=$ high, comparable to sour orange; $\mathrm{M}=$ medium, comparable to Swingle citrumelo; $\mathrm{L}=$ low, comparable to Flying Dragon trifoliate orange.

parent was used in all experiments (Grosser and Gmitter, 1990; Grosser et al., 2000). Fusions were conducted in $60 \times 15-\mathrm{mm}$ polystyrene petri dishes using our standard PEG (40\% polyethylene glycol) volumetric plating method (Grosser and Gmitter, 1990). Following fusion, protoplasts were cultured initially in a $1: 1(\mathrm{v}: \mathrm{v})$ mixture of $0.6 \mathrm{~m} \mathrm{BH} 3$ and $0.6 \mathrm{~m}$ EME protoplast culture media (Grosser and Gmitter, 1990), and sealed petri dishes were maintained in plastic boxes under low light. A typical experiment resulted in 10 to 20 fusion petri dishes per parental combination, depending on protoplast yields.

Plant recovery. Regenerating calli were transferred to solid EME medium containing $50 \mathrm{~g} \cdot \mathrm{L}^{-1}$ sucrose or maltose (Perez et al., 1998) for somatic embryo induction according to Grosser and Gmitter (1990). Most but not all of small regenerated embryos were cultured over $0.22-\mu \mathrm{m}$ cellulose acetate membrane filters placed on fresh plates of EME-maltose solid medium to normalize and enlarge the embryos (Niedz and Bausher, 2002). Large somatic embryos, usually exhibiting abnormal shapes, were screened for ploidy level using a Partec flow cytometer (model D-48161; Münster, Germany). Only confirmed tetraploid embryos were transferred directly to DBA3 medium for shoot induction (Deng et al., 1992). Developing shoots were rooted on RMAN medium (Grosser and Gmitter, 1990). Plantlets transferred to the greenhouse were covered with rigid clear plastic for 2 to 3 weeks for acclimation.

RANDOMLY AMPLIFIED POLYMORPHIC DNA (RAPD) ANALYSIS. Total DNA was extracted from leaves of putative tetraploid somatic hybrids of mandarin + pummelo and their related parents for random amplified polymorphic DNA (RAPD) analysis, using a GenElute plant genomic DNA kit by Sigma. DNA samples were amplified using a DNA thermal cycler (model 480; Perkin Elmer). The following random primers were used: C-11 and C-64 (suggested by K. Kepenek, personal communication, and obtained from Operon Technologies, Alameda, Calif.). Sequences of C-11 and C-64 were AGGTACGCCCGA and CCAGATCCGAAT,

Fig.1. Leaf morphology of some putative somatic hybrids of mandarin + pummelo. (R1,2, and $3=$ rows 1,2 and $3 ; \mathrm{P}=$ parent; $\mathrm{SH}=$ somatic hybrid).R1-left to right: $\mathrm{P} 1=$ sour orange, $\mathrm{P} 2=$ Amblycarpa, $\mathrm{P} 3$ = Shekwasha, $\mathrm{P} 4=$ 'Murcott', $\mathrm{P} 5=\mathrm{HBP}$. R2-left to right: $\mathrm{SH}=$ Shekwasha $+\mathrm{HBP}, \mathrm{SH}=$ 'Murcott' + HBP sdl-JL-1, SH = 'Murcott' + HBP. R3-left to right: $\mathrm{SH}=$ Amblycarpa + C. grandis 'Chandler', $\mathrm{SH}$ $=$ Amblycarpa $+\mathrm{HBP}, \mathrm{SH}=$ Amblycarpa + HBP sdl-JL-2B, SH = Amblycarpa + HBP sdl-5-1-99-1B, SH = Amblycarpa + 'LingPing Yau'-sdl-8-1-99-4A.

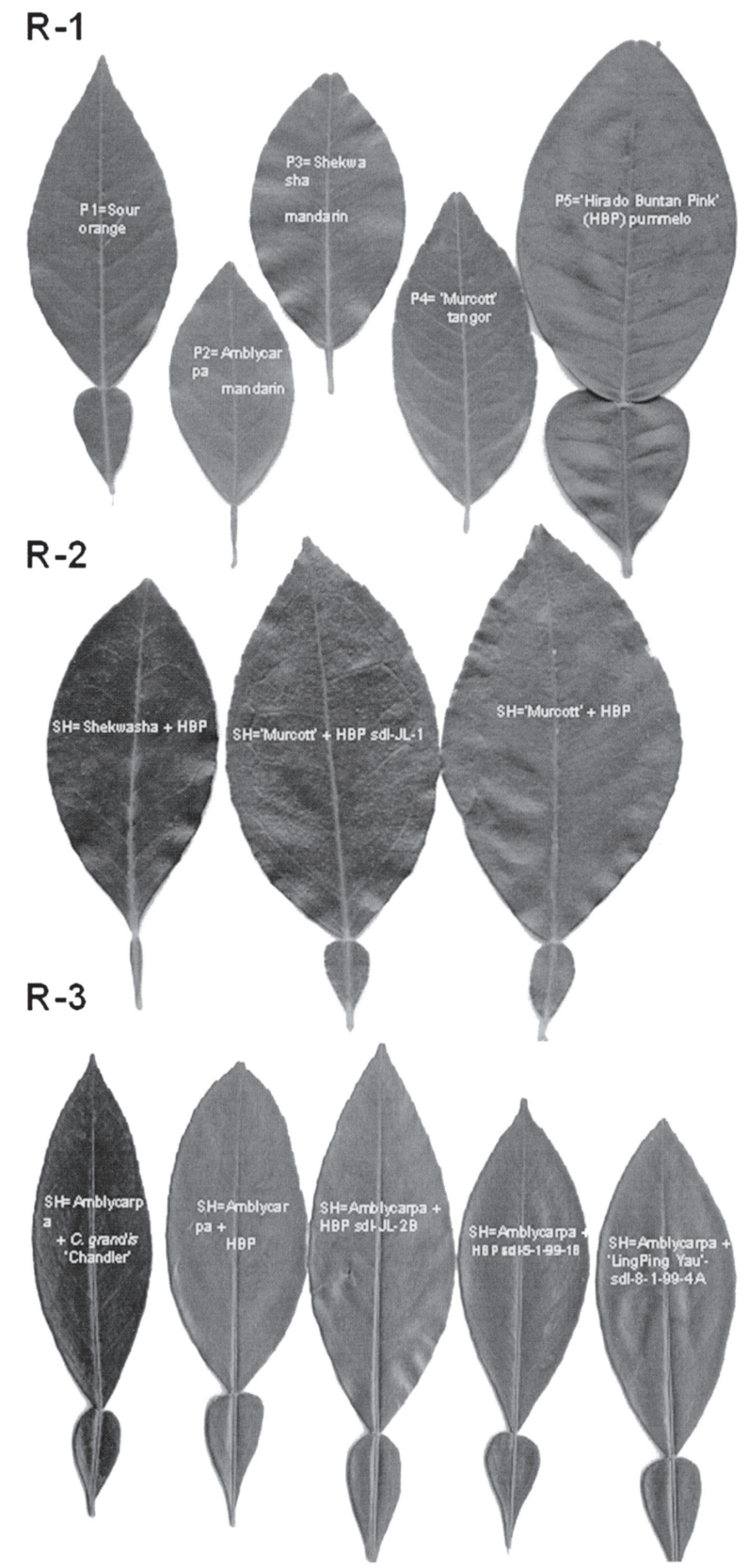

J. Amer. Soc. Hort. ScI. 129(4):530-534. 2004. 


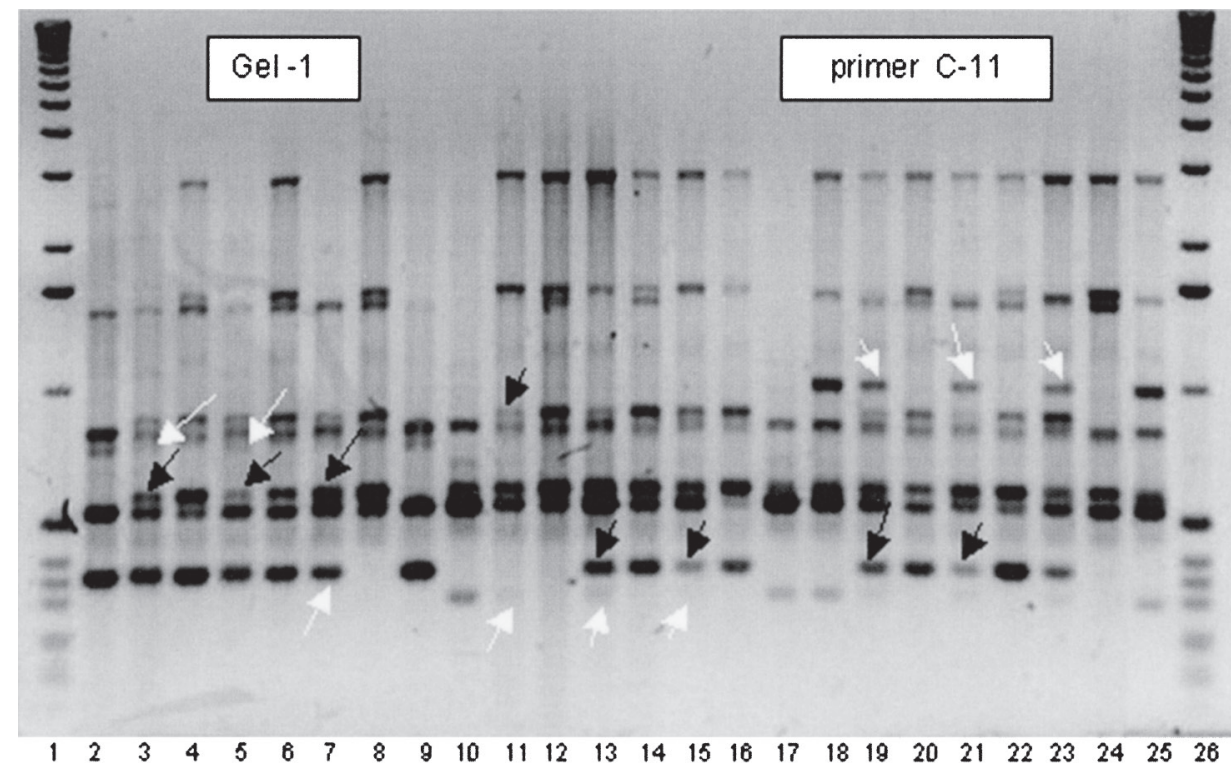

respectively. Amplification of DNA was performed under the following reaction conditions: one cycle of $2 \mathrm{~min}$ at 94 ${ }^{\circ} \mathrm{C}$; followed by 34 cycles for $1 \mathrm{~min}$ of denaturing at $94^{\circ} \mathrm{C} ; 1 \mathrm{~min}$ of annealing at $42{ }^{\circ} \mathrm{C}$ and a 2 -min extension at $72{ }^{\circ} \mathrm{C}$; a final extension for $10 \mathrm{~min}$ at $72{ }^{\circ} \mathrm{C}$. Amplification products were separated on a $1 \%$ agarose gel containing $1 \times \mathrm{TAE}$ buffer and $0.5 \mu \mathrm{g} \cdot \mathrm{mL}^{-1}$ ethidium bromide for $2.5 \mathrm{~h}$ at $2.3 \mathrm{~V} \cdot \mathrm{cm}^{-1}$, and visualized under UV light.

\section{Results and Discussion}

RECOVERY OF SOMATIC HYBRIDS. SOmatic hybrid plants were recovered from the 12 mandarin + pummelo parental combinations listed in Table 1. All pummelo sources provided consistently excellent yields of high-quality leaf protoplasts,

Fig. 2. RAPD patterns of interspecific somatic hybrids and their parental genotypes. Gel-1 products amplified by operon primer C-11. Lanes 1 and $26=1-\mathrm{kb}$ marker; 2 = Shekwasha mandarin $(C$. depress $) ; 3=$ Shekwasha + 'Chandler'; $4=$ 'Chandler'; 5= Shekwasha +HBP sdl-JL-2B, 6= HBPsdl-JL-2B; 7 = Shekwasha + HBP; 8 = HBP; 9 = Shekwasha; $10=$ 'Murcott' tangor; $11=$ 'Murcott' $+C$. grandis 'Hirado Buntan Pink' (HBP); $12=C$. grandis 'Hirado Buntan Pink' $($ HBP $) ; 13$ = 'Murcott' + HBP sdl-JL-1; 14 = HBP sdl-JL-1; 15 = 'Murcott' + 'Chandler' sdl. \#80; 16 = 'Chandler' sdl. \#80; 17 = 'Murcott'; 18 = Amblycarpa mandarin $(C$. amblycarpa $) ; 19=$ Amblycarpa + HBP sdl-JL-2B; $20=$ HBP sdl.JL-2B; 21 = Amblycarpa + 'Chandler'sdl.69; 22 = 'Chandler' sdl.69; 23 = Amblycarpa + HBP sdl-5-1-99-1B; 24 = HBP sdl-5-1-99-1B; 25 =Amblycarpa.

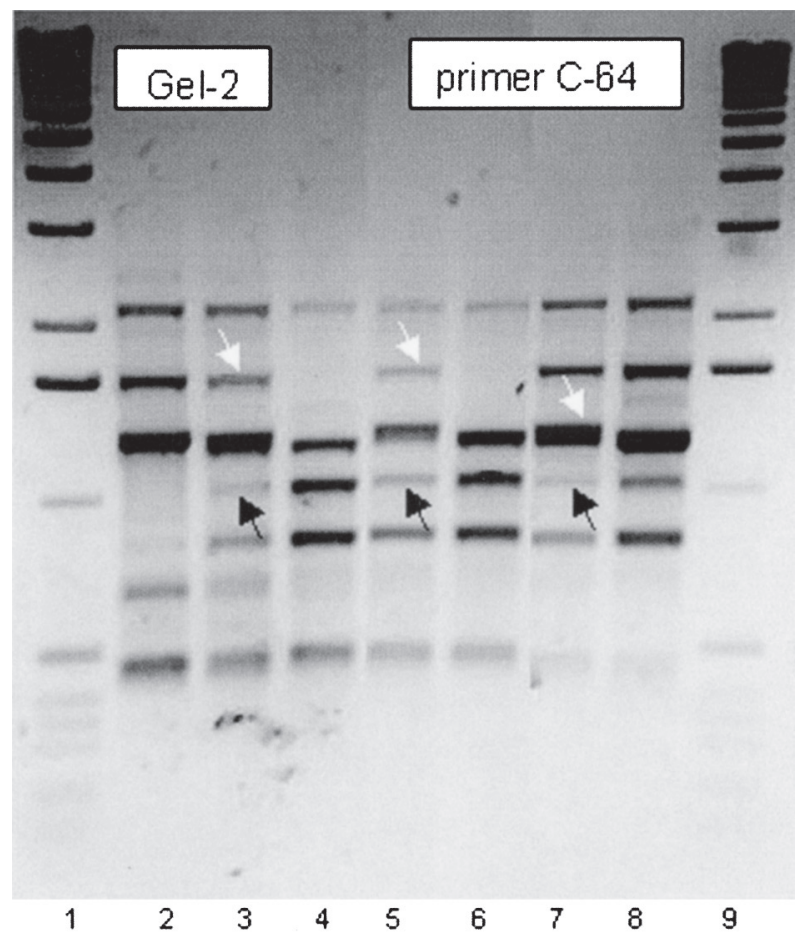

Fig. 3. RAPD patterns of interspecific somatic hybrids and their parental genotypes. Gel-2 products amplified by operon primer C-64. Lanes 1 and $9=1-\mathrm{kb}$ marker; $2=$ Amblycarpa mandarin $($ C. amblycarpa $) ; 3=$ Amblycarpa + HBP; $4=\mathrm{HBP}$; 5 = Amblycarpa + 'LingPing Yau'-sdl-8-1-99-4A; 6 = 'LingPing Yau'-sdl-81-99-4A; 7 = Amblycarpa $+C$. grandis 'Chandler'; $8=C$. grandis 'Chandler'. White arrows indicate complementary bands from the embryogenic mandarin parents and black arrows from the pummelo leaf parents. making pummelo more reliable for use in fusion experiments than other citrus types such as mandarins or trifoliate orange. High plating efficiencies were observed on most fusion petri dishes, and mats of regenerating callus covered the entire surface on many of the plates. Embryo formation was sporadic and did not occur on all plates. Small green globular and heart-shaped embryos were transferred to fresh plates of solid EME-maltose, usually on circular pieces of cellulose acetate membranes which enhanced embryo growth and development. Since the Amblycarpa and Shekwasha suspension cultures were still totipotent, recovered somatic embryos from all fusion experiments were screened for ploidy level using flow cytometry. Numerous diploid embryos from fusions involving Amblycarpa and Shekwasha

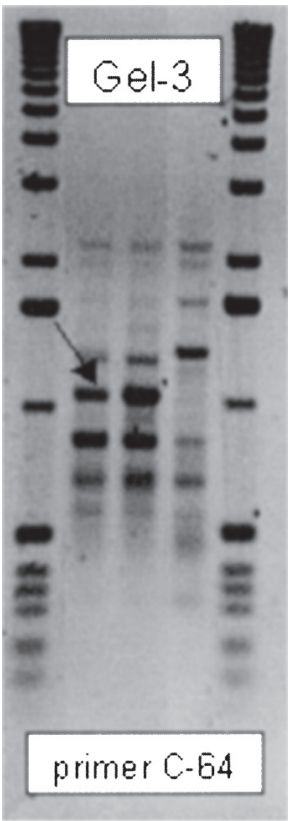

12345 were discarded, which eliminated considerable subsequent unnecessary tissue culture and greenhouse work. No diploid embryos were recovered from fusions involving 'Murcott'. Tetraploid somatic embryos from all combinations were quite large and often exhibited abnormal shape (more so than for the discarded diploid embryos). However, most of them yielded multiple shoots when cultured on DBA3 medium. Shoots from all combinations rooted readily on RMAN medium, and greenhouse acclimation was almost $100 \%$ successful.

SOMATIC HYBRID VERIFICATION. All somatic hybrids exhibited leaf morphologies intermediate to that of their parents. The somatic hybrids with Amblycarpa (and to some extent with 'Murcott') had leaf morphologies very similar to that of sour orange (Fig. 1). However the somatic hybrids with Shekwasha exhibited more narrow leaf petiole wings (Fig. 1). Most

Fig. 4. RAPD patterns of interspecific somatic hybrids and their parental genotypes. Gel-3 products amplified by operon primer C-64. Lanes 1 and $5=1-\mathrm{kb}$ marker, 2 = Amblycarpa + HBP sdl-5-1-99-1B; 3 = HBP sdl-5-1-99-1B; 4 = Amblycarpa. Black arrow indicates complementary band from the pummelo leaf parent. 
of the somatic hybrids were also quite vigorous (Table 1) and showed excellent nursery performance (straight upright singlestem growth with wide girth for easy budding) with the exception of the Shekwasha hybrids, which flushed less frequently and appeared to have shorter internodes. In general, fewer plants were recovered from the 'Murcott' and Shekwasha fusions due to less efficient embryo induction. Also, the Amblycarpa hybrids were more vigorous in culture and generally produced multiple shoots per embryo on DBA3 medium. Some bi-foliate and trifoliate leaves were observed on the somatic hybrid of Amblycarpa + 'Chandler'. New somatic hybrids with Shekwasha had narrower leaf petiole wings than expected, but we have also observed this with diploid sexual hybrids between Shekwasha and HBP (J.W. Grosser, unpublished data).

All regenerated somatic hybrid plants were tetraploid as confirmed by flow cytometry. RAPD analysis using total genomic DNA of the somatic hybrids and their parents were displayed through gel electrophorosis using primer C-11 and C-64. Primer $\mathrm{C}$-11 showed complementary parental banding pattern in the DNA of the somatic hybrids from most parental combinations (Fig. 2); and somatic hybrids not verified by C-11 exhibited complementary parental banding patterns using primer C-64 (Figs. 3 and 4). All RAPD analyses for hybrid verification were run at least twice.

\section{Concluding Remarks}

All of the new somatic hybrids reported herein are being propagated for further evaluation including testing for resistance to CTV-induced quick decline disease. Many rooted cuttings have already been produced from Amblycarpa + 'HBP', Amblycarpa + 'HBP' sdl 5-1-99-1B, and Amblycarpa + 'Ling Ping Yau zyg.' Sdl 8-1-99-4A. These hybrids have also been budded with sweet orange and grapefruit for inclusion in replicated commercial trials, including a blight resistance trial. All of the new somatic hybrids reported herein are being topworked to mature field trees to expedite flowering and fruiting. It will require several years to determine if any of these hybrids can be propagated by nucellar seed, the standard method of citrus rootstock propagation. Hybrids of pummelo and mandarin can be completely monoembryonic, completely polyembryonic, or anywhere in between. In the event that any of these somatic hybrids show good rootstock performance but do not produce adequate nucellar seed, they should be amenable to propagation by rooted cuttings. Some Florida nurseries are currently propagating certain rootstocks by cuttings (including 'Kinkoji') at a cost comparable to that of seedlings (Philip Rucks, personal communication).

Our previous approach to develop a replacement for sour orange was to produce somatic hybrids of sour orange with complementary CTV-tolerant and resistant rootstocks (Grosser and Gmitter, 1990; Grosser et al., 2000). Some of these sour orange somatic hybrids showed resistance to CTV-induced quick decline in a greenhouse assay (Grosser et al., 1996), and some also are showing good horticultural performance and ability to control tree size (Grosser et al., 1995; Grosser and Chandler, 2002). However, these hybrids have not in general performed as well as expected on challenging high $\mathrm{pH}$, calcareous soil types including the Winder depressional type described herein. Based on the use of selected superior parents, the mandarin + pummelo hybrids reported herein should be more widely adapted and have potential for good field tolerance to citrus blight. Several years of field testing will be required to determine if yield, fruit quality, fruit holding capacity, and survivability will be adequate for any of these mandarin + pummelo hybrids to replace sour orange.

\section{Literature Cited}

Bar-Joseph, M., R. Marcus, and R.F. Lee. 1989. The continuous challenge of citrus tristeza virus control. Annu. Rev. Phytopathol. 27:291-316.

Barrett, H.C. and A.M. Rhodes. 1976. A numerical taxonomic study of affinity relations in cultivated citrus and its close relatives. Syst. Bot. 1:105-136.

Brown, M.G. and T.H. Spreen. 2000. An economic assessment of the impact of the citrus tristeza virus on the Florida grapefruit industry. Proc. Fla. State Hort. Soc. 113:79-82.

Campbell, C.W. 1991. Rootstocks for the 'Tahiti' lime. Proc. Fla. State Hort. Soc. 104:28-30.

Castle, W.S. 1983. Growth, yield and cold hardiness of seven-year-old 'Bearss' lemon trees on twenty-seven rootstocks. Proc. Fla. State Hort. Soc. 96:23-25

Castle, W.S. 1987. Citrus rootstocks, p. 361-399. In: R.C. Rom and R.F. Carlson (eds.). Rootstocks for fruit crops. Wiley, New York.

Castle, W.S. 2003. Early maturing sweet oranges: Research update on Earlygold, Itaborai, Ruby and Westin. Citrus Ind. 84:19-22.

Castle, W.S., R.R. Pelosi, C.O. Youtsey, F.G. Gmitter, Jr., R.F. Lee, C.A. Powell, and X. Hu. 1992. Rootstocks similar to sour orange for Florida citrus trees. Proc. Fla. State Hort. Soc. 105:56-60.

Castle, W.S., D.P.H. Tucker, A.H. Krezdorn, and C.O. Youtsey. 1993. Rootstocks for Florida citrus, p. 1-92. 2nd ed. Univ. Fla., IFAS, Gainesville.

Deng, X.X., J.W. Grosser, and F.G. Gmitter, Jr. 1992. Intergeneric somatic hybrid plants from protoplast fusion of Fortunella crassifolia cultivar 'Meiwa' with Citrus sinensis cultivar 'Valencia.' Scientia Hort. 49:55-62.

Fang, D.Q. and M.L. Roose. 1999. A novel gene conferring citrus tristeza virus resistance in Citrus maxima (Burm.) Merrill. HortScience 34:334-335.

Grosser, J.W. and J.L. Chandler. 2002. Somatic hybridization for citrus rootstock improvement. Proc. 7th Intl. Citrus Seminar-Improvement. Estacao Experimental De Citricultura De Bebedouro, SP, Brazil. Grosser, J.W. and F.G. Gmitter, Jr. 1990. Protoplast fusion and citrus improvement. Plant Breed. Rev. 8:339-374.

Grosser, J.W., F.G. Gmitter, Jr., and W.S. Castle. 1995. Production and evaluation of citrus somatic hybrid rootstocks: Progress report. Proc. Fla. State Hort. Soc. 108:140-143.

Grosser, J.W., S.M. Garnsey, and C. Halliday. 1996. Assay of sour orange somatic hybrid rootstocks for quick-decline disease caused by citrus tristeza virus. Proc. Intl. Soc. Citricult. 1:353-356.

Grosser, J.W., J. Jiang, E.S. Louzada, J.L. Chandler, and F.G. Gmitter, Jr. 1998. Somatic hybridization an integral component of citrus cultivar improvement: II. Rootstock improvement. HortScience 33:1060-1061.

Grosser, J.W., P. Ollitrault, and O. Olivares-Fuster. 2000. Somatic hybridization in citrus: An effective tool to facilitate variety improvement. In Vitro Cell Dev. Biol-Plant 36:434-449.

Hodgson, R.W. 1967. Horticultural varieties of citrus, p. 431-591. In: W. Reuther, H.J. Webber, and L.D. Batchelor (eds.). The citrus industry. vol. 1. Univ. Calif., Riverside.

Medina-Urrutia, V.M. 1996. Comportamiento de portainjertos de limón mexicano en Colima. INIFAP-CIRPAC-Campo Experimental Tecoman. Folleto Tecnico 3. p. 36.

Nicolosi, E., Z.N. Deng, A. Gentile, and S. La Malfa. 2000. Citrus phylogeny and genetic origin of important species as investigated by molecular markers. Theor. Appl. Genet. 100:1155-1166.

Niedz, R.P. and M.C. Bausher. 2003. Improved induction and development of sweet orange (Citrus sinensis (L.) Osbeck) somatic embryos from embryogenic callus. In Vitro Cell Dev. Biol. Plant 38:552-557.

Perez, R.M., A.M. Galiana, L. Navarro, and N. Duran-Vila. 1998. Embryogenesis in vitro of several Citrus species and cultivars. J. Hort. Sci. Biotechnol. 73:796-802.

Saunt, J. 1990. Citrus varieties of the world. Sinclair Intl., Norwich, U.K. Swingle, W.T. and P.C. Reece. 1967. The botany of citrus and its wild relatives, p. 190-430. In: W. Reuther, H.J. Webber, and L.D. Batchelor (eds.). The citrus industry. vol. 1. Univ. Calif., Riverside.

Yokomi, R.K., R. Lastra, M.B. Stoetzel, V.D. Amsteegt, R.F. Lee, S.M. Garnsey, T.R. Gottwald, M.A. Rocha-Pena, and C.L. Niblett. 1994. Establishment of the brown citrus aphid (Homoptera: Aphidadae) in Central America and the Carribean Basin and transmission of citrus tristeza virus. J. Econ. Entomol. 87:1078-1085. 